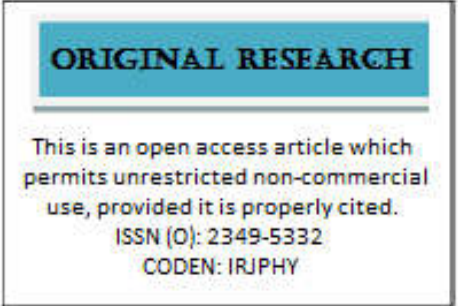

\section{FORMULATION AND EVALUATION OF IBUPROFEN GASTRO RETENTIVE FLOATING \\ TABLETS}

Department of Pharmaceutics, MLR Institute of Pharmacy, Dundigal, Medchal, Telangana, India.

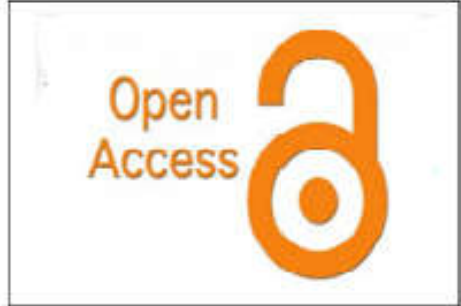

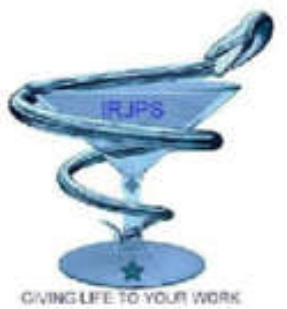

evisctorto voun woas

\section{Maheshwar}

Submitted on: 21.12.18;

Revised on: 04.01.19;

Accepted on: 08.01.19

\begin{abstract}
The objective of the present study was to formulate the optimised gastro-retentive floating tablets containing Ibuprofen, which would remain in upper part of GIT for prolonged period of time. Ibuprofen is a medication in the non steroidal anti-inflammatory drug class that is used for treating pain, fever, and inflammation. Floating systems will have low bulk density so that they can float on the gastric juice in the stomach. Ibuprofen is an anti inflammatory drug. Various approaches have been followed to encourage gastric retention of an oral dosage form. The present work attempts have been made to prepare Ibuprofen by Direct compression method. On trial and error basis formulation design was carried. Four different batches of floating tablets of Ibuprofen were prepared using HPMC, Xanthan gum, and gas generating agent sodium bicarbonate and citric acid. The tablets were subjected to pre compression parameters such as Angle of repose, bulk density, tapped density, Hausner's ratio and Carr's index and post compression parameters such as friability, hardness, thickness, drug content, weight variation, in-vitro buoyancy studies and in-vitro drug release studies and the results were within the limits. From the results obtained, it was concluded that the optimized formulation F4 was having desired drug release properties and floating behaviour when compared with that of marketed product.
\end{abstract}

KEYWORDS: Ibuprofen, gastro-retentive floating tablets, Xanthan gum, sodium bicarbonate, citric acid.

Corresponding Author: M. Maheshwar E-mail: maheeshh02@gmail.com
Indian Research Journal of Pharmacy and Science; 19(2018)1718-1725 Journal Home Page: https://www.irjps.in DOI: 10.21276/irjps.2018.5.4.11 


\section{INTRODUCTION}

Administration of drugs by oral route offers ease administration and gastrointestinal physiology offers more flexibility in dosage form design than other routes ${ }^{1}$. Drugs that are easily absorbed from gastrointestinal tract (GIT) and have short half lives are eliminated quickly from the systemic circulation. So, there is need of frequent dosing of these drugs is required to achieve desired therapeutic activity. To avoid this, the development of oral sustained/controlled release formulations is an attempt to release the drug slowly into the GIT and maintain an effective drug concentration in the systemic circulation for a long time. Floating drug delivery systems (FDDS) were first described by Davis in $1968^{2}$. Floating systems or Hydrodynamically controlled systems are low-density systems that have sufficient buoyancy to float over the gastric contents and remain buoyant in the stomach without affecting the gastric emptying rate for a prolonged period of time while the system is floating on the gastric content; the drug is released slowly at the desired rate from the floating system. After release of drug, the residual system is emptied from the stomach ${ }^{3}$. This results in an increased Gastric retention time and a better control of the fluctuations in plasma drug concentration ${ }^{4}$. Gastro retentive systems confine the dosage forms for several hours inside the stomach and considerably prolong the gastric residence time of drugs $^{5}$. Prolonged gastric retention improves bioavailability, reduces drug waste, and improves solubility for drugs that are less soluble in a high $\mathrm{pH}$ environment. It is also beneficial for local drug delivery to the stomach and proximal small intestines $^{6}$. Ibuprofen (iso-butyl-propanoic-phenolic acid) is a non-steroidal anti-inflammatory drug (NSAID). It is a propionic acid derivative ${ }^{7}$. It is used for treatment of rheumatoid arthritis, degenerative joint disease, osteoarthritis, acute musculoskeletal disorders, and low back pain, fever. The bioavailability of the drug is $87-100 \%$ and the protein binding capacity is $98 \%{ }^{8}$. It is metabolized by liver and it has a plasmatic half-life of 1.8-2.0 hr as a result, it has to be administered three to six times a day. It is excreted through urine ${ }^{9}$. Hydrophilic polymer matrix is widely used for formulating sustained release dosage form. HPMC is widely used hydrophilic polymer to prolong drug release due to its rapid hydration, good compression and gelling characteristics along with its ease of use, availability, and very low toxicity. It regulates the release of drug by controlling the swelling and cross-linking ${ }^{10,11}$. The main intention of this work was to formulate a single unit floating tablets of ibuprofen with use of HPMC for the release of the drug after a definite lag time and provides required concentration of drug at regular intervals of time which results reduction in frequency of dose of administration and will improve patient compliance ${ }^{12}$.

\section{MATERIALS AND METHODS}

Ibuprofen was obtained as a gift sample from Vive Med Labs, Hyderabad, Telangana, India. HPMC K4M, Xanthan gum, Citric acid, lactose and Sodium bicarbonate, Talc and MCC were obtained from Research Lab, Hyderabad, Telangana, India. All the chemicals and reagents required for the present experimental work are of analytical grade.

\section{Standard Calibration Curve}

$10 \mathrm{mg}$ of Ibuprofen was weighed and dissolved in $10 \mathrm{ml}$ of phosphate buffer 6.8 , to give a solution of $1000 \mu \mathrm{g} / \mathrm{ml}$ concentration. From this solution $1 \mathrm{ml}$ was taken and diluted to $10 \mathrm{ml}$ using Phosphate buffer 6.8 to produce a stock solution of $100 \mu \mathrm{g} / \mathrm{ml}$. From this stock solution different concentrations were prepared. The absorbance of these solutions was measured at $221 \mathrm{~nm}$ by UV spectrophotometer ${ }^{13}$. The standard curve of the ibuprofen shown in the Figure-1.

Table 1: Standard Curve of Ibuprofen

\begin{tabular}{|l|l|l|}
\hline S. No & $\begin{array}{l}\text { Concentration } \\
(\boldsymbol{\mu g} / \mathbf{m l})\end{array}$ & Absorbance \\
\hline 1 & 10 & 0.340 \\
\hline 2 & 20 & 0.548 \\
\hline 3 & 30 & 0.724 \\
\hline 4 & 40 & 0.862 \\
\hline 5 & 50 & 0.974 \\
\hline
\end{tabular}


Preparation of Ibuprofen floating tablets

The composition of different formulations of Ibuprofen floating tablets is shown in Table-2. All the ingredients were accurately weighed and passed through the sieve 60 . In order to mix the ingredients thoroughly drug and polymer were blended and geometrically in a mortar and pestle for 15 minutes then magnesium stearate, sodium bicarbonate, talc, lactose and magnesium stearate were mixed one by one. After thoroughly mixing the ingredients, the powder was mixture was passed through the sieve 44 and compressed on rotary tablet punching machine ${ }^{14,15}$.

Table-2: Formulation Development of Ibuprofen floating tablets

\begin{tabular}{|l|l|l|l|l|l|l|l|l|l|}
\hline $\begin{array}{l}\text { atch } \\
\text { code }\end{array}$ & $\begin{array}{l}\text { Ibuprofen } \\
(\mathbf{m g})\end{array}$ & $\begin{array}{l}\text { HPMC } \\
\text { K4M } \\
(\mathbf{m g})\end{array}$ & $\begin{array}{l}\text { Xanthan } \\
\text { gum } \\
(\mathbf{m g})\end{array}$ & $\begin{array}{l}\text { NaHCO3 } \\
(\mathbf{m g})\end{array}$ & $\begin{array}{l}\text { M.C.C } \\
(\mathbf{m g})\end{array}$ & $\begin{array}{l}\text { Citric } \\
\text { acid } \\
(\mathbf{m g})\end{array}$ & $\begin{array}{l}\text { Lactose } \\
(\mathbf{m g})\end{array}$ & $\begin{array}{l}\text { Magnesium } \\
\text { stearate } \\
(\mathbf{m g})\end{array}$ & $\begin{array}{l}\text { Talc } \\
(\mathbf{m g})\end{array}$ \\
\hline F1 & 100 & 25 & 12 & 20 & 38 & 15 & 13 & 5 & 5 \\
\hline F2 & 100 & 12 & 25 & 18 & 38 & 12 & 11 & 5 & 5 \\
\hline F3 & 100 & 37 & 37 & 25 & 38 & 18 & 18 & 5 & 5 \\
\hline F4 & 100 & 50 & 50 & 30 & 38 & 25 & 20 & 5 & 5 \\
\hline
\end{tabular}

Pre compression parameters of Ibuprofen floating tablets

1. Angle of Repose: It is defined as the maximum angle that can be obtained between the free standing of powder heap and horizontal plane. It was determined by the following equation.

\section{$\operatorname{Tan} \boldsymbol{\theta}=\mathbf{h} / \mathbf{r}$}

Where, $\theta=$ Angle of repose. $\mathrm{h}=$ powder heap. $\mathrm{r}=$ Radius of the powder cone.

2. Bulk Density: It refers to packing of particles. The bulk density of the formulated granules was evaluated using a bulk density apparatus ${ }^{16}$. It is expressed in $\mathrm{gm} / \mathrm{ml}$ and is given as

Bulk density=Mass of the powder/ bulk volume of the powder

3. Tapped density: Weighed quantity of tablet blend was introduced into a graduated cylinder. Volume occupied by the drug was noted down. Then cylinder was subjected to 100, 200 and300 taps in tap density apparatus ${ }^{17}$. According to USP, tapped density was given by

\section{Tapped density=Mass of the powder/Tapped volume of the powder}

\section{Carr's Index (Compressibility)}

The compressibility index and Hausner ratio was measures the property of powder to be compressed. The packing ability of tablet blend was evaluated from change in volume, which is due to rearrangement of packing occurring during tapping $^{18}$. It was indicated as Carr's compressibility index was calculated by following formula.

\section{Carr's index $=\underline{\text { Tapped density }- \text { Bulk density }} \mathbf{x}$ 100 \\ Tapped density}

5. Hausner's Ratio: It is measurement of frictional resistance of tablet blend ${ }^{19}$. The ideal range should be 1.2-1.5. It was determined by the ratio of tapped density and bulk density.

\section{Hausner's ratio=Tapped density/Bulk density}

Table-3: Specifications for flow properties

\begin{tabular}{|l|l|l|l|}
\hline Flow Character & Carr's index (\%) & Hausner's ratio & Angle of repose \\
\hline Excellent & $<10$ & $1.00-1.11$ & $25-30$ \\
\hline Good & $11-15$ & $1.12-1.18$ & $31-35$ \\
\hline $\begin{array}{l}\text { Fair (aid not } \\
\text { needed) }\end{array}$ & $16-20$ & $1.19-1.25$ & $36-40$ \\
\hline $\begin{array}{l}\text { Passable (may hang } \\
\text { up) }\end{array}$ & $21-25$ & $1.26-1.34$ & $41-45$ \\
\hline $\begin{array}{l}\text { Poor (must } \\
\text { agitate/vibrate) }\end{array}$ & $26-31$ & $1.35-1.45$ & $46-55$ \\
\hline Very poor & $32-37$ & $1.46-1.59$ & $56-65$ \\
\hline Very, very poor & $>38$ & $>1.60$ &.$>66$ \\
\hline
\end{tabular}


Table-4: Results of Pre compression parameters of Ibuprofen powder blend

\begin{tabular}{|l|l|l|l|l|l|}
\hline $\begin{array}{l}\text { Batch } \\
\text { code }\end{array}$ & $\begin{array}{l}\text { Angle of } \\
\text { repose }(\boldsymbol{\theta})\end{array}$ & $\begin{array}{l}\text { Bulk } \\
\text { Density }(\mathbf{g m} / \mathbf{m l})\end{array}$ & $\begin{array}{l}\text { Tapped } \\
\text { Density }(\mathbf{g m} / \mathbf{m l})\end{array}$ & $\begin{array}{l}\text { Carr's } \\
\text { Index (\%) }\end{array}$ & $\begin{array}{l}\text { Hausner's } \\
\text { ratio }\end{array}$ \\
\hline F1 & 21 & 0.224 & 0.264 & 15.15 & 1.17 \\
\hline F2 & 22 & 0.222 & 0.260 & 14.61 & 1.17 \\
\hline F3 & 26 & 0.251 & 0.289 & 13.14 & 1.15 \\
\hline F4 & 25 & 0.229 & 0.260 & 11.92 & 1.13 \\
\hline
\end{tabular}

Post compression parameters of Ibuprofen floating tablets

\section{Weight variation test}

Twenty Ibuprofen tablets were weighed individually, average weight was calculated and individual tablet weights were compared to the average weight. The tablets met the USP test if no more than two tablets are outside the percentage limit and if no tablet differs by more than two times the percentage limit ${ }^{20}$.

\section{Hardness test}

The hardness of the tablets was determined using Monsanto Hardness tester ${ }^{21,22}$. It is expressed in $\mathrm{kg} / \mathrm{cm}^{2}$. Six tablets were randomly picked from each formulation and the mean and standard deviation values were calculated.

\section{Friability}

A friability test was conducted on Ibuprofen floating tablets using a Roche friabilator. Twenty tablets were selected from each batch and any loose dust was removed with the help of a soft brush. The tablets were initially weighed and transferred into friabilator $^{23}$. The drum was rotated at $25 \mathrm{rpm}$ for 4 minutes after which the tablets were removed. Any loose dust was removed from the tablets as before and the tablets were weighed again ${ }^{24,25}$. The percentage friability was then calculated by

\section{$\%$ Friability $=\underline{\text { Initial weight }- \text { Final weight }} \times$ 100 \\ Final weight}

\section{Lag Time}

The In vitro buoyancy was determined by the lag time. The Ibuprofen tablets were placed in a $100 \mathrm{ml}$ beaker containing $0.1 \mathrm{~N} \mathrm{HCl}$. The time required for a tablet to rise to the surface for floating was determined as the lag time ${ }^{26}$.

\section{Floating Time}

The Ibuprofen tablets were placed in a $100 \mathrm{ml}$ glass beaker containing $0.1 \mathrm{~N} \mathrm{HCl}$. The time for which the tablet remained floating on the surface of medium was determined as floating time ${ }^{27}$.

\section{Drug Content}

Ten Ibuprofen tablets were weighed and average weight was calculated. All the 10 tablets were crushed in a mortar. The powder equivalent to 10 $\mathrm{mg}$ was accurately weighed, dissolved in $5 \mathrm{ml}$ of Methanol and made up to $100 \mathrm{ml}$ with $0.1 \mathrm{~N} \mathrm{HCl}$. The volumetric flask was then shaken for approximately 20 minutes. The solution was filtered and $1 \mathrm{ml}$ of filtrate was diluted to $10 \mathrm{ml}$ using $0.1 \mathrm{~N} \mathrm{HCl}$. Absorbance was measured at 221 nm using $0.1 \mathrm{~N} \mathrm{HCl}$ as a blank solution ${ }^{28}$. The amount of drug present in one tablet was calculated.

\section{In vitro drug release studies}

In vitro drug release study for the prepared Ibuprofen floating tablets were conducted for period of 15 hours using a six station USP XXVI type II (paddle) apparatus at $37 \pm 0.5^{\circ} \mathrm{C}$ and $50 \mathrm{rpm}$ speed. The dissolution studies were carried out for 15 hours in phosphate buffer of $\mathrm{pH} 6.8$ under sink condition. At first one hour and then every two hours of time interval samples of $5 \mathrm{ml}$ were withdrawn from dissolution medium and replaced with fresh medium to maintain the volume of dissolution medium constant. After filtration and appropriate dilution, the sample solution was analyzed at $221 \mathrm{~nm}$ for Ibuprofen by a UVspectrophotometer.

\section{RESULTS AND DISCUSSION}

Floating tablets of Ibuprofen were developed in order to increase the gastric residence time of drug, so that they can be retained in stomach for longer time to reduce the frequency of administration. Four different batches of tablets were made using HPMC K4M, along with effervescing agent sodium bicarbonate and citric acid to optimize the drug content, in vitro buoyancy and in vitro drug dissolution studies. The selection of viscosity grade of a polymer is an important consideration in the formulation of tablet. All the formulations were prepared by direct compression method. Absorption maxima of the Ibuprofen were determined by UV spectrophotometric method 
using UV/Visible spectrophotometer. The $\lambda_{\max }$ of Ibuprofen in phosphate buffer 6.8 is $221 \mathrm{~nm}$. These results of post compression parameters are shown in the Table-5.

Table-5: Results of Post compression parameters of Ibuprofen floating tablets

\begin{tabular}{|l|l|l|l|l|l|l|}
\hline $\begin{array}{l}\text { Batch } \\
\text { code }\end{array}$ & $\begin{array}{l}\text { Average } \\
\text { weight } \mathbf{( g m )}\end{array}$ & $\begin{array}{l}\text { Hardness } \\
\left(\mathbf{k g} / \mathbf{c m}^{2}\right)\end{array}$ & $\begin{array}{l}\text { Friability } \\
\mathbf{( \% )}\end{array}$ & $\begin{array}{l}\text { Buoyancy } \\
\text { lag time } \\
\text { (sec) }\end{array}$ & $\begin{array}{l}\text { Total } \\
\text { floatation } \\
\text { time (hrs) }\end{array}$ & $\begin{array}{l}\text { Drug } \\
\text { Content } \\
\text { (\%) }\end{array}$ \\
\hline F1 & 0.485 & 3.7 & 0.7 & 120 & $>10$ & 98.86 \\
\hline F2 & 0.492 & 6.3 & 0.3 & 100 & $>8$ & 98.32 \\
\hline F3 & 0.500 & 4.2 & 0.5 & 200 & $>10$ & 97.58 \\
\hline F4 & 0.468 & 5.9 & 0.2 & 240 & $>11$ & 99.57 \\
\hline
\end{tabular}

The release profiles of formulations F1, F2, F3, F4 and marketed product are shown in Figure 2. Maximum release was shown by formulation of batch F4 in the duration of 15 hrs when compared with the marketed product. The difference in burst effect was the result of difference in the viscosity of the polymers. It is reported that citric acid level greatly influenced the drug release, irrespective of hydroxy propyl methyl cellulose grade. Lactose was used as diluents as well as channelling agent in the floating delivery of the drug. In vitro release profile showed that on increasing the concentration of lactose release rate increased. Floating lag time for formulations of batches was found to in the range of 100 to $240 \mathrm{sec}$. The concentration of gas generating agent affected the floating lag time, as the amount of gas-generating agent was increased, the floating lag time decreased.

Table-6: Cumulative Percentage Drug Release of Ibuprofen floating tablets

\begin{tabular}{|l|l|l|l|l|l|}
\hline $\begin{array}{l}\text { Time } \\
\text { (hrs) }\end{array}$ & F1 & F2 & F3 & F4 & $\begin{array}{l}\text { Marketed } \\
\text { product }\end{array}$ \\
\hline 1 & 1.62 & 6.32 & 6.45 & 7.26 & 7.52 \\
\hline 3 & 9.21 & 9.61 & 10.25 & 11.74 & 10.68 \\
\hline 5 & 14.23 & 13.21 & 13.25 & 15.95 & 14.96 \\
\hline 7 & 21.32 & 20.51 & 17.24 & 23.51 & 22.35 \\
\hline 9 & 22.34 & 21.54 & 19.32 & 29.61 & 28.55 \\
\hline 11 & 23.36 & 22.36 & 25.36 & 32.54 & 33.62 \\
\hline 13 & 36.52 & 32.51 & 29.92 & 38.51 & 37.42 \\
\hline 15 & 38.61 & 35.61 & 36.32 & 46.62 & 45.51 \\
\hline
\end{tabular}

The incorporation of gas generating agent exhibited reduction in the floating lag time. After the analysis of the above formulation and optimization study we can conclude that optimized formulation of batch F4 is the best and promising formulation for the delivery of the Ibuprofen in order to provide the controlled release and increased gastro retentive drug delivery system to reduce frequency of its administration. 


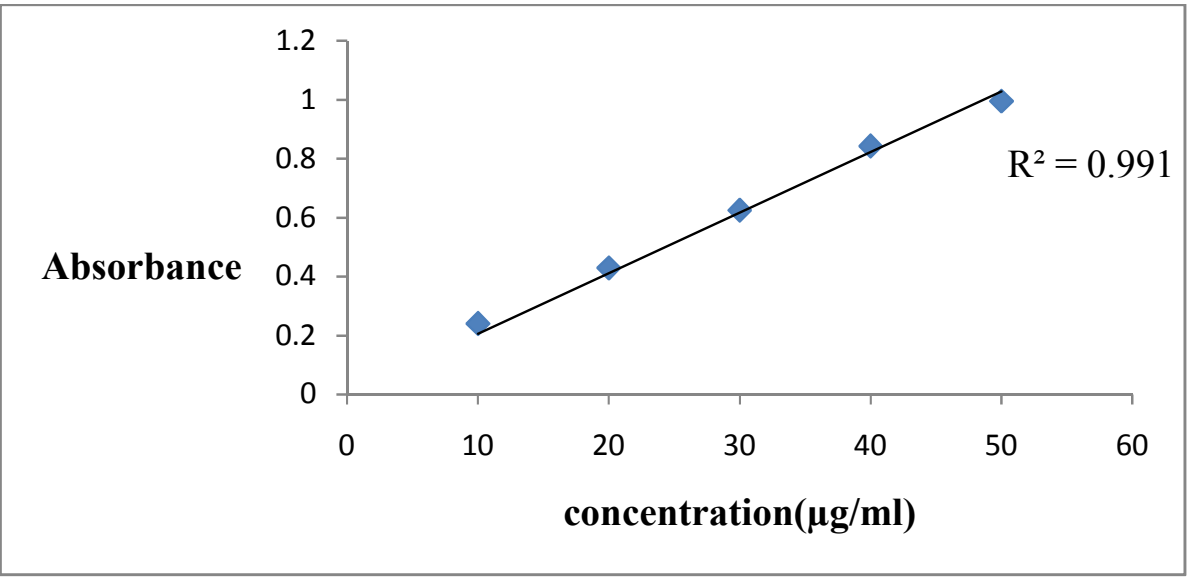

Figure-1: Standard graph of Ibuprofen

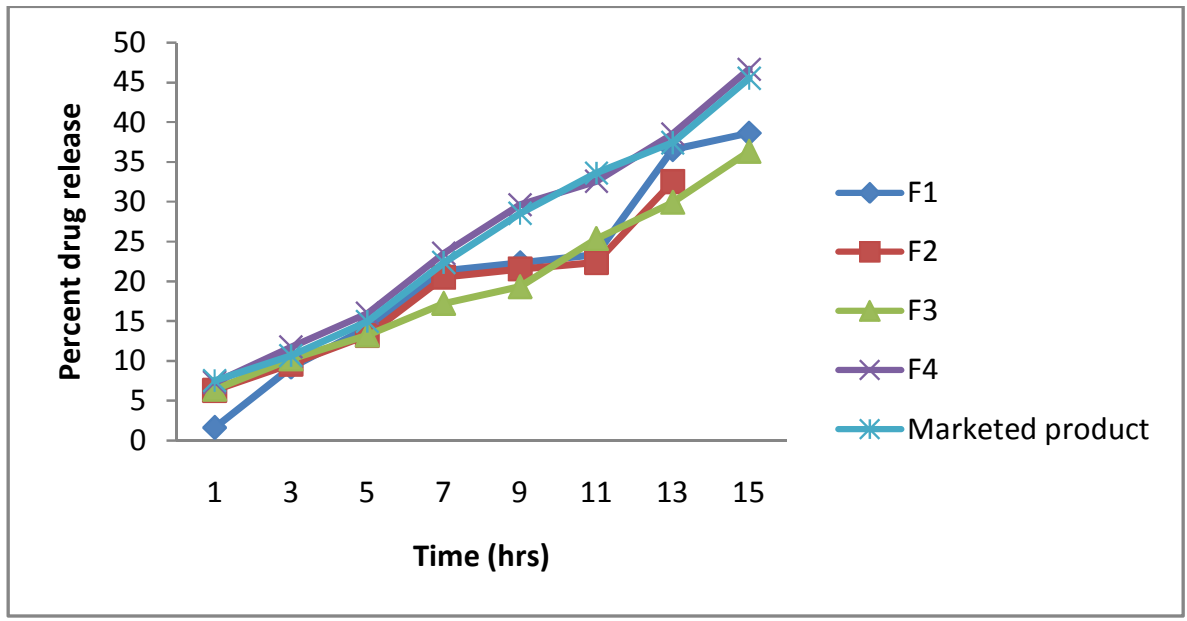

Figure-2: In vitro drug release of Ibuprofen floating tablets

\section{CONCULSION}

The ultimate aim of the present study was to prepare gastro retentive floating tablet of Ibuprofen using polymers like HPMC K4M by direct compression method. Different pre compression properties like Carr's Index, Hausner ratio, bulk density and tapped density indicate good flow properties of powder. The formulations were evaluated for various parameters like hardness, friability, weight variation, floating lag time, floating time, in-vitro drug release etc. Based on different evaluation parameters formulation of batch F4 was concluded as an optimized formulation compared with that of marketed

\section{REFERENCES}

1. Sonar GS, Jain DK. Prepatation and in vitro Evaluation of bilayer and floating - bioadhesive product. The present research work was successful in improving the efficacy of Ibuprofen oral therapy as the drug release was extended reducing dosing frequency thereby improving patient compliance.

\section{ACKNOWLEDGEMENT}

The author was Thankful to Dr. K. S. Murali Krishna, Principal, MLR Institute of Pharmacy for his kind support and encouragement.

\section{CONFLICT OF INTEREST}

No conflict of interest was associated with this work.

tablet of Rosiglitazone Maleate. Asian J Pharm Sci. 2004; 1(4), 161-169 
2. Igwe J. Chibueze, Emenike IV, Oduola AR. Formulation and evaluation of Finasteride sustained-release matrix tablets using different rate controlling polymers. Univ J Pharm Res. 2016; 1(2): 25-31.

3. Arora S, Ali J, Ahuja A, Khar RK, Baboota S. Floating drug delivery systems: a review. AAPS Pharmsci tech. 2005; 6 (3) Article 475.

4. Vendruscolo CW, Andreazza IF, Ganter JL, Ferrero $\mathrm{C}$ and Bresolin TM. "Xanthan and galactomann matrix tablets based for oral controlled delivery of theophylline. Int. $\mathrm{J}$ pharm. 2005; 296: 1-11.

5. Chandran S, Laila FA, Design and evaluation of Ethyl Cellulose Based Matrix Tablets of Ibuprofen with $\mathrm{pH}$ Modulated Release Kinetics. Indian J Pharm Sci. 2008; 3(4): 418-423.

6. Seifert, SA; Bronstein, AC; McGuire, T. Massive ibuprofen ingestion with survival. Journal of Toxicology. Clinical Toxicology. 2000; 38 (1): $55-7$.

7. Davanzo R, Bua J, Paloni G, Facchina G. Breast feeding and migraine drugs. Europ $\mathrm{J}$ Clin Pharmacol. 2014; 70 (11): 1313-24.

8. Rainsford KD. Discovery, mechanisms of action and safety of ibuprofen. Int J Clin Prac. 2003; 135: 3-8.

9. Ziyaur R, Mushir A and Khar RK. Design and Evaluation of bilayer floating tablets of captopril. Acta pharmaceutica. 2006; 56: 49-57.

10. Paert Zhang J, Massart MH. Feasibility study of the use of near Infrared spectroscopy in the quantitative analysis of

green tea, camellia sinesis. Analytica chimica Acta. 2003; 478(2):303-312.

11. Varshosaz J, Tavakoli N. Formulation and evaluation of sustained release matrix tablet of asprin. AAPS Pharm Sci Tech. 2006; 7(1): 13-18.

12. Chandran S, Laila FA. Design and evaluation of Ethyl Cellulose Based Matrix Tablets of Ibuprofen with $\mathrm{pH}$ Modulated Release Kinetics. Indian J Pharm Sci. 2008; 3(4): 418-423.

13. Ikechukwu UR, John Francis DE, Ambi AA. Development and evaluation of Ritonavir hollow microballoons for floating drug delivery. Univ $\mathrm{J}$ Pharm Res. 2017; 2(2): 30-34.

14. Fukuda M, Peppas NA, Mc Ginity JW. A floating hot-melt extruded tablets for gastroretentive controlled drug release system. J Cont Rel. 2006; 115:121-129.

15. Kristl J, Baumgartner S, Vodopivec P, Zorko B. Optimisation of floating matrix tablets and evaluation of their gastric residence time. Int $\mathrm{J}$ Pharm. 2000; 195:125-135.

16. Tadros MI. Controlled-release effervescent floating matrix tablets of ciprofloxacin hydrochloride: Development, optimization and in vitro-in vivo evaluation in healthy human volunteers. Europ J Pharm Biopharm. 2010; 74:332-339.

17. Elmowafy EM, Awad GAS, Mansour S, El Shammy. Release Mechanisms Behind Polysaccharides-Based Famotidine Controlled Release Matrix Tablets. AAPS. Pharm. Sci. Tech. 2008; 9(4):1230-1239.

18. Felix Sunday Yusuf. Formulation and in-vitro evaluation of floating microballoons of stavudine. Univ J Pharm Res. 2016; 1(1): 13-19.

19. Timmermans J, Moes A J: Factors controlling and gastric retention capabilities of floating matrix capsules: New data for reconsidering the controversy. J Pharm Sci. 1994; 83 (1): 18-24.

20. Dave BS, Amin AF, Patel MM. Gastro retentive drug delivery system of ranitidine hydrochloride: formulation and in vitro evaluation, AAPS Pharm Sci Tech. 2004; 5: E34.

21. Jimenez M, Quirino-barreela IJ. Sustained delivery of floating matrix labeled. Ind $\mathrm{J}$ Pharm. 2008; 362:37-4B.

22. Kendre PN, Lateef SN, Godge RK, Chaudhari PD, Fernandes SL, Vibhute SK. Oral sustained delivery of theophylline floating matrix tabletsformulation and in-vitro evaluation. Int $\mathrm{J}$ Pharm Tech Res. 2010; 2(1), 130-139.

23. Yonezava $\mathrm{Y}$, Ishida S, Sunanda S. Release from or through a wax matrix system: I, basic release properties of the wax matrix system. Chem Pharm Bull. 2001; 49:1448e51.

24. Klausner EA, Lavy E, Barta M, Cserepes E, Friedman M, Hoffman A. Novel gastroretentive dosage forms: Evaluation of gastroretentivity and its effect on levodopa absorption in humans. Pharm Res. 2003; 20:1466-73.

25. Anyanwu NCJ, Adogo LY, Ajide B. Development and evaluation of in situ gelling gastroretentive formulations of Meloxicam. Univ $\mathbf{J}$ Pharm Res. 2017; 2(3): 11-14.

26. Wu W, Zhou Q, Zhang HB, Ma GD, Fu CD. Studies on nimodipine sustained release tablet capable of floating on gastric fluid with prolonged gastric resident time. Yao Xue Xue Bao. 1997; 32:786-90

27. Li S, Lin S, Daggy BP, Mirchandani HL, Chein YW. Effect of HPMC and carbopol on the release 
and the floating properties of gastric floating drug delivery system using factorial design. Int J Pharm. 2003; 253:13-22.
28. Verma BK, Pandey S, Arya P. Tablet granulation: current scenario and recent advances. Univ J Pharm Res. 2017; 2(5): 34-39. 